\title{
EXAMINATION OF SLEEP QUALITY, ANXIETY AND DEPRESSION IN STROKE PATIENTS
}

\author{
Esra DOGRU HUZMELI*, Elif Tugba SARAC**
}

\author{
*Mustafa Kemal University, School of Physical Therapy and Rehabilitation, Hatay, TURKEY \\ **Mustafa Kemal University, Medical Faculty of Tayfur Ata Sökmen, Ear-Nose-Throat Department, \\ Audiology Unit, Hatay, TURKEY
}

\begin{abstract}
INTRODUCTION: Different level of sleep problems, depression and anxiety are common in stroke patients. The aim of the present study was to examine the sleep quality, anxiety and depression in stroke patients and to examine effect of duration of the disease on that symptoms.

METHODS: Hemiplegic patients admitted to the Mustafa Kemal University Hospital Neurology Department, during 1 year and accepted to participate to the study were included $(n=30)$. Demographic data, duration of the hemiplegia were recorded. Patients' sleep quality was assessed with The Pittsburgh Sleep Quality Index, depression with The Beck Depression Inventory, anxiety with Generalized Anxiety Disorder Scale and cognitive status with the Mini Mental State Examination.

RESULTS: It was found that $40 \%$ of the patients' cognitive status was normal and the remain had different level of cognitive impairment. 33.3\% of the patients had severe generalized anxiety disorder and only $10 \%$ of them depression status was normal. We found that $53.3 \%$ of the subjects had poor sleep quality. The correlation between Beck Depression Inventory and The Pittsburgh Sleep Quality Index was significant, positive and moderate. Beck Depression Inventory had significant, positive and moderate correlation with Generalized Anxiety Disorder Scale too. Other correlations were mild and not significant. We find that duration did not affect the anxiety, the sleep quality, depression and body mass index. DISCUSSION and CONCLUSION: We found that there was a relationship between sleep quality and depression; depression and anxiety. Psychological state affects the sleep quality and vice versa. Duration of the disease did not affect the sleep quality, depression, anxiety and there was not any difference between male and female sex in these symptoms.

Keywords: Sleep quality, anxiety, depression, stroke, stroke' complication.
\end{abstract}

\section{İNMELİ HASTALARDA UYKU KALİTESİ, ANKSIYETE VE DEPRESYONUN İNCELENMESI}

\section{ÖZET}

GİRIȘ ve AMAÇ: İnmeli hastalarda farklı düzeylerde uyku problemleri, depresyon ve anksiyete sıklıkla görülmektedir. Çalışmamızın amacı inmeli hastalarda uyku kalitesi, anksiyete ve depresyonu ve hastalık durasyonunun bu semptomlar üzerine etkisini incelemektir.

YÖNTEM ve GEREÇLER: Çalıșmaya Mustafa Kemal Üniversitesi Nöroloji Anabilim Dalı'na bir yıl içinde bașvuran ve çalışmaya katılmayı kabul eden hemiplejik hastalar dahil edildi $(n=30)$. Demografik bilgiler, hemiplejinin durasyonu kaydedildi. Hastaların uyku kalitesi, Pittsburgh Uyku Kalitesi Ölçeği ile; depresyon düzeyi, Beck Depresyon İndeksi ile; anksiyete, Genel Anksiyete Ölçeği ile; mental durum, Mini Mental Test ile değerlendirildi.

BULGULAR: Hastaların \%40'ının mental durumlarının normal olduğu, geri kalanının farklı düzeyde mental bozukluğu olduğu bulundu. Hastaların \%33.3'ünün Genel anksiyete bozukluğu vardı ve hastaların sadece \%10'unun depresyon durumları normaldi. Hastaların \%53.3'ünün zayıf uyku kalitesi olduğu bulundu. Beck Depresyon İndeksi ile Pitspurg Uyku Kalitesi Ölçeği arasında anlamlı, pozitif ve orta düzeyde korelasyon vardı. Beck Depresyon İndeksi aynı zamanda Genel Anksiyete Bozukluğu ölçeği ile pozitif ve anlamlı orta düzeyde korelasyon bulundu. Diğer korelasyonlar zayıftı ve anlamlı değildi. Hastalığın durasyonunun anksiyete, uyku kalitesi, depresyon ve vücut kitle indeksini etkilemediğini bulduk.

TARTIŞMA ve SONUÇ: Uyku kalitesi ile depresyon ve depresyon ile anksiyete arasında ilişki olduğunu bulduk. Psikolojik durum uyku kalitesini, uyku kalitesi de psikolojik durumu etkiler. Hastalığın durasyonunun uyku kalitesi, depresyon, anksiyeteyi etkilemediğini ve kadın erkek arasında bu semptomlarda fark olmadığını bulduk.

Anahtar Sözcükler: Uyku kalitesi, anksiyete, depresyon, inme, inme komplikasyonu.

Corresponding author: Esra Dogru Huzmeli, PhD. Mustafa Kemal University, School of Physical Therapy and Rehabilitation, Hatay, Turkey.

Telephone: +903262455516 E-mail: esradogru001@hotmail.com

Received: 23.01.2017 Accepted: 11.05.2017

This article should be cited as following: Dogru Huzmeli E, Saraç E.T. Examination of sleep quality, anxiety and depression in stroke patients. Turkish Journal of Cerebrovascular Diseases 2017; 23 (2): 51-55. doi:10.5505/tbdhd.2017.81905 


\section{INTRODUCTION}

Stroke is defined as an acute neurological deficit lasting for more than 24 hours. It is caused by a cerebral blood flow abnormality resulting in signs and symptoms associated with compromised focal brain areas (1). Many different complications are seen after stroke. Motor and non-motor symptoms affect stroke survivers' activities of daily living, psychology, social relationships and participation. Mood, cognitive and sleep disorders are commonly seen in those with cerebrovascular disease and these symptoms interact each other.

Studies suggest that having a stroke increases the risk of anxiety and depression (2). Clinically, anxiety can be potentially serious and disabling with manifold adverse consequences. Considerable symptom overlap exists between anxiety and depressive disorders (3). Post-stroke depression affects disability level, cognitive status and vice versa. The frequency of major depression seems to increase during the first year $(4,5,6,7)$.

The occurrence of sleep disorders is an important aspect that needs to be considered in the clinical approach to patients with stroke because of its prevalence. In a study, it was found that stroke patients suffer from lower sleep quality than that of healthy individuals (8).

Different level of sleep problems, depression and anxiety are common among stroke patients. The aim of the present study was to examine the sleep quality, anxiety and depression in stroke patients and to examine the effects of disease duration on that symptoms.

\section{MATERIAL AND METHODS}

All patients admitted to the Mustafa Kemal University Hospital Neurology Department with hemiplegic symptoms during 1-year period and accept to participate the study were included $(\mathrm{n}=30)$. Mean age was 61.20 years (range, 37 to 75 years); 22 were male and 8 were female. Demographic data, duration of the hemiplegia, Body Mass Index (BMI) were recorded. Patients' sleep quality was assessed with The Pittsburgh Sleep Quality Index, depression with The Beck Depression Inventory, anxiety with Generalized Anxiety Disorder Scale and cognitive status with the Mini Mental State Examination. We included patients that can understand and answer our tests and questions. The study was applied in Turkish patients. So, the scales' Turkish valid and reliable forms were used.

The Pittsburgh Sleep Quality Index (PSQI) is an instrument used to measure the quality of sleep in adults. It differentiates from "poor" to "good" sleep quality (10).

The Beck Depression Inventory (BDI) includes 21-item, self-report rating inventory that measures characteristic attitudes and symptoms of depression. Total score of BDI 1-10 is considered normal, 11-16 mild mood disturbance, 17-20 borderline clinical depression, 21-30 moderate depression, 31-40 severe depression, over 40 extreme depression $(11,12)$.

Generalized Anxiety Disorder (GAD) Scale is a widely used self-report measure developed to screen for GAD. Total score of GAD 0-4 is considered minimal, 5-9 mild, 10-14 moderate, 1521 severe (13).

The Mini Mental State Examination (MMSE) is a tool that can be used to systematically and thoroughly assess mental status. The maximum score is $30(14,15)$.

\section{Statistical Analyses}

Statistical analysis was performed by using the statistical SPSS Package Program, version 20. A type I error level of 5\% was used to infer statistical significance. Kruskal Wallis and Mann-Whitney U tests were used to analyze difference between scales. For correlation between numerical variables, we used Spearman's correlation. Correlation is an effect size and so verbally described the strength of the correlation using the guide that Evans (16) suggests for the absolute value of r: 0.00-0.19 "very weak", 0.200.39 "weak", 0.40-0.59 "moderate", 0.60-0.79 "strong", 0.80-1.0 "very strong".

\section{RESULTS}

Both chronic and acute stroke patients were included in the study. Most of the patients' Body Mass Index (BMI) score was normal (Table 1). Twenty-six of them were married, one of them was single and the others were divorced. Cigarette history questioned and found $46.7 \%$ of patients had never used, $43.3 \%$ ex-smoker and $6.7 \%$ was still using.

It was found that $40 \%$ of the patients' cognitive status was normal and the remaining had different level of cognitive impairment. 33.3\% of the patients had severe anxiety and only $10 \%$ of 
them depression status was normal. We found that $53.3 \%$ of the subjects had poor sleep quality (Table 2).

We analyzed the effects of disease duration on PSQI, GAD and BDI. There was no significant difference between duration of the disease and PSQI ( $p=0.869)$, GAD $(p=0.580)$ and BDI $(p=0.258)$. There was no significant difference between duration of the disease and BMI $(\mathrm{p}=0.089)$.

We analyzed difference between gender and symptoms. There was no significant difference between Male and female patients on BDI $(\mathrm{p}=0.790)$, PSQI (0.285), GAD ( $p=0.851)$.

PSQI had significant, positive and moderate correlation with BDI $(\mathrm{r}=0.543, \mathrm{p}=0.002)$, mild correlation with GAD ( $r=0.395, p=0.031)$. BDI had significant, positive and moderate correlation with GAD ( $\mathrm{r}=0.577, \mathrm{p}=0.001)$.

Table 1. Demographic characteristics of patients.

\begin{tabular}{lll}
\hline \multicolumn{1}{l}{ Gender } & n & \% \\
Female & 8 & 26.7 \\
Male & 22 & 73.3 \\
Education & & \\
Illiterate & 5 & 16.7 \\
Primary School & 16 & 53.3 \\
Secondary School & 2 & 6.7 \\
High School & 5 & 16.7 \\
University & 2 & 6.7 \\
Duration & & \\
6 months & 10 & 33.3 \\
$6.1-24$ months & 10 & 33.3 \\
$24.1-60$ months & 6 & 20.0 \\
60.1 and more & 4 & 13.3 \\
BMI & & \\
$18.5-20$ & 1 & 3.3 \\
$21-25$ & 17 & 56.7 \\
$26-30$ & 12 & 40.0 \\
\hline
\end{tabular}

Table 2. Cognitive status, depression, sleep quality and anxiety status of the patients.

\begin{tabular}{lcc}
\hline MMSE & n & \% \\
\hline Severe cognitive impairment & 9 & 30.0 \\
Mild cognitive impairment & 9 & 30.0 \\
No cognitive impairment & 12 & 40.0 \\
GAD & & \\
Mild & 10 & 33.3 \\
Moderate & 10 & 33.3 \\
Severe & 10 & 33.3 \\
BDI & & \\
Normal & 3 & 10.0 \\
Mild mood disturbance & 7 & 23.3 \\
Borderline clinical depression & 9 & 30.0 \\
Moderate depression & 8 & 26.7 \\
Severe depression & 3 & 10.0 \\
Extreme depression & 0 & 0 \\
PSQI & & \\
Normal & 14 & 46.7 \\
Poor sleep quality & 16 & 53.3 \\
\hline
\end{tabular}

\section{DISCUSSION}

In the present study, we planned to examine depression, anxiety, and sleep quality in stroke patients and we found that there was a relationship between sleep quality and depression; depression and anxiety. Psychological state affects the sleep quality and vice versa. Duration of the disease did not affect the sleep quality, depression, anxiety and there was not any difference between male and female sex and these symptoms.

We found $53.3 \%$ of the patients had poor sleep quality. Sleep quality is an important factor for normal functional activities. Patricia et al. suggest that complaints of poor sleep quality and insomnia should be given priority in the assessment (17). In another study, it was found that stroke patients suffer from lower sleep quality than that of healthy individuals. So, complaints of poor sleep quality should be given priority assessment during clinical diagnosis (8). Clinicians mostly focus on motor problems and neglect nonmotor features. But if the patient has healthy motor and nonmotor features, the function is better, the quality of life is higher. So, the rehabilitation program should include not only motor functions, but also nonmotor features.

Atlig et al. found that poor sleep quality and depression affect functional status negatively in hemiplegic patients (18). Most of our subjects had problems with sleep quality and had depression. But we didn't examine functional status of the patients, so we did not research the relationship between motor and non-motor features. It is one of our limitation. We recommend for future studies to examine motor functions too. 53.3\% of the patients had poor sleep quality, it is a huge rate. Sleep quality is important for healthy mood, hear a healtlthy daily living activities even in healthy people. Hemiplegic patients might have other problems and Their life is affected worse with poor sleep quality. Worse sleep quality causes more depression and more depression results with poor sleep quality. We have to break this vicious circle to heal the patient.

GAD after stroke is common and long-lasting. Monica et al. found a substantial interference with social relationships and functional recovery. GAD will make heavy demands on early and effective treatment (3). No information was available for stroke patients with anxiety only (19). We found that $33.3 \%$ of the patients had severe GAD.

Turkish Journal of Cerebrovascular Diseases 2017; 23 (2): 51-55 
GAD affects the rehabilitation program's success so it should be considered in the assessment of the stroke patients.

We found a moderate correlation between GAD and depression. There is a strong link between depression and anxiety disorders. Depression and anxiety share many symptoms in common so their separation is not easy.

Having a stroke can affect the way in which people think and feel. Mood depression is a common and serious complication after stroke. According to epidemiological studies, nearly $30 \%$ of stroke patients develop depression, either in the early or in the late stages after stroke. Somatic symptoms like psychomotor retardation, and disturbances in appetite, sleep, and sexual interest, depression are commonly observed problems (6, 20 ). In our study, $10 \%$ of the patient's depression status was normal, but the others had different level of depression. The rate of depression is high among our stroke patients

We found a relationship between depression and sleep quality. It means that depressive patients had more sleep disorders and vice versa. Health is a state of complete physical, mental and social well-being. Patients live depression because of stroke, and this triggers sleep disorders, sleep disorders triggers depression more. For a healthy life, the patient need healthy mood, good sleep, functional motor and non-motor features

A study was reported that the long disease duration affects the development of depression. But we find that duration does not affect the depression (21). It may be because our study group was small and most of our patients' disease duration was less than 24 months. In the future studies, more subjects should be included. In a study intra-individual comparisons showed that the frequency of GAD did not decrease significantly between 3 and 12 months (22). We find that duration did not affect the anxiety level.

In the present study, we searched the relation between anxiety and depression in stroke patients and to examine the effects of disease duration on that symptoms. We have some limitations in our study. We have a small number of stroke patients. Functional status of the patients should be examined. In future studies, a control group should be included to understand the problems caused by stroke or by another reason. Duration of the disease was not homogene, this may affect our results and we did not question anatomic localization of the stroke. There are few studies

Turkish Journal of Cerebrovascular Diseases 2017; 23 (2): 51-55 that examined the relationship between anxiety, depression and sleep quality in stroke patients. So, our study contributes important data to the literature. But future studies may be planned with bigger subject groups.

\section{REFERENCES}

1. World Health Organization. WHO STEPS Stroke Manual: The WHO STEPwise approach to stroke surveillance. Geneva: World Health Organization; 2005, ISBN 9241594047, NLM classification: WT 355. http://www.who.int/chp/steps/Manual.pdf?ua=1

2. http://www.strokeassociation.org/STROKEORG/LifeAfterS troke/RegainingIndependence/EmotionalBehavioralChalle nges/PostStrokeMoodDisorders_UCM_467460_Article.jsp\#. WAdK0uWLSM8. Accessed time: 19.10.2016

3. Åström M. Generalized Anxiety Disorder in Stroke Patients. A 3-Year Longitudinal Study Stroke. 1996;27:270-275.

4. Kauhanen ML, Korpelainen JT, Hiltunen P, et al. Aphasia, depression, and non-verbal cognitive impairment in ischaemic stroke. Cerebrovasc Dis. 2000;10:455-61.

5. Schwartz JA, Speed NM, Brunberg JA, et al. Depression in stroke rehabilitation. Biol Psychiatry.1993;33:694-9.

6. Paolucci S. Epidemiology and treatment of post-stroke depression Neuropsychiatr Dis Treat. 2008, 4(1): 145-154.

7. Kauhanen M, Korpelainen JT, Hiltunen P, et al. Poststroke depression correlates with cognitive impairment and neurological deficits. Stroke. 1999;30:1875-80.

8. Campos TF , Barroso MTM , Silveira ABG, Melo LP , Dantas AATSG, Araujo JF. Sleep disturbances complaints in stroke: implications for sleep medicine. Sleep Sci. 2013;6(3):98102.

9. Buysse DJ, Reynolds CF 3rd, Monk TH, Berman SR, Kupfer DJ. The Pittsburgh Sleep Quality Index: a new instrument for psychiatric practice and research. Psychiatry Res. 1989 28(2):193-213.

10. Ağargün MY, Kara H, Anlar Ö. Pittsburgh Uyku Kalitesi İndeksinin Geçerliği ve Güvenirliği, Türk Psikyatri, 1996; 7(2): 107-115.

11. Hisli N. Beck Depresyon Envanterinin Geçerliği Üzerine Bir Çalışma. Psikoloji Dergisi, 1988 (22) 118-126.

12. 12. Beck AT, Ward CH, Mendelson, Mock J, \& Erbaugh J. An inventory for measuring depression. Archives of General Psychiatry, 1961, 4, 561-571.

13. Spitzer RL, Kroenke K, Williams JB, et al. A brief measure for assessing generalized anxiety disorder: the GAD-7. Arch Intern Med. 2006, 166(10):1092-7.

14. Folstein MF, Folstein SE, McHugh PR: "Mini-mental state: A practical method for grading the cognitive state of patients for the clinician." J Psychiatr Res 1975;12:189-198.

15. Güngen C, Ertan T, Eker E, Yaşar R, Engin F. Standardize Mini Mental Test'in Türk Toplumunda Hafif Demans Tanısında Geçerlik ve Güvenilirliği Türk Psikiyatri Dergisi 2002; 13(4):273-281.

16. Evans JD. Straightforward statistics for the behavioral sciences. Pacific Grove, CA: Brooks/Cole Publishing 1996.

17. Rocha PCD, Barroso MTM, Dantas AATSG, Melo LP and Campos TF .Predictive factors of subjective sleep quality and insomnia complaint in patients with stroke: implications for clinical practice. An Acad Bras Cienc 2013, 85 (3) 1197-1206.

18. Atlig RF, İçağasioğlu A, Yumuşakhuylu y, Turgut ST, Selimoğlu E. İnmeli hastalarda uyku kalitesi ve depresyon fonksiyonel durumu etkiler mi? Göztepe Tıp Dergisi 2012, 27(4):167-173, 19. 
19. Campbell Burton CA, Holmes J, Murray J, Gillespie D, Lightbody CE, Watkins CL, Knapp P. Interven-tions for treating anxiety afte $r$ stroke. Cochrane Database of Systematic Reviews 2011, Issue 12. Art. No.: CD008860. DOI:10.1002/14651858.CD008860.pub2.

20. Kellermann M, Fekete I, Gesztelyi R, et al. Screening for depressive symptoms in the acute phase of stroke. Gen Hosp Psychiatry. 1999;21:116-21.
21. Karaahmet OZ, Gurcay E, Avluk OC, Umay EK, Gundogdu I, Ecerkale O, Cakci A. Poststroke depression: risk factors and potential effects on functional recovery.Int J Rehabil Res. 2017, 40(1):71-75.

22. Castillo S, Starkstein SE, Fedoroff P, Price TR, Robinson RG. Generalized anxiety after stroke. J Nerv Ment Dis. 1993;181:100-106. 